\title{
Corruption in Africa: The Way Forward
}

\author{
Sa-ad Iddrisu* \\ Department of Economics, Wayne State University, 656 W. Kirby St, 2110 FAB, Detroit, MI, 48202, United \\ States \\ *Corresponding Author: Sa-ad Iddrisu, Department of Economics, Wayne State University, 656 W. \\ Kirby St, 2110 FAB, Detroit, MI, 48202, United States
}

\begin{abstract}
The slogans by African leaders such as "Africa Beyond Aid" by the President of Ghana, Nana Akufo-Addo, would continue to be an empty slogan if the fight against corruption is not won within the continent. Corruption is an act of deviation from good and causes the African continent to lose revenue. African governments must take the fight against corruption seriously by increasing punishment for offenders, increasing surveillance on governments' agents, and commercializing the fight against corruption. By doing so the continent would excel in controlling these prominent acts of corruption by government agents, thereby leading to more revenue being accrued for developmental purposes.
\end{abstract}

Keywords: Africa, Corruption, Economic Growth, Good, Government, Sustainable Development.

\section{INTRODUCTION}

How do I tell a story and contribute to restrict a monster that causes trillions of dollars that could have been used for national development, to be lost to private individual pockets, leaving most of the populace in abject poverty and lack of basic needs? That is the question I ask myself every day as an individual from an African country, Ghana. Corruption has gained global attention and researchers and international organizations have attempted to define and measure it. One of such organizations is the Transparency International (TI). TI is the most widely used corruption indicator and it uses a scale of 0 to 100 to rank countries, where 0 is highly corrupt and 100 is very clean. TI [1] defines corruption as "the abuse of entrusted power for private gain." Macrae [2] uses the term "arrangement" to define corruption. The arrangement involves a private exchange between two parties (the demander and the supplier) which has an immediate or future influence on resource allocation, and the use of public office for private means. The basic assumption of his definition is that, corruption is a rational calculus and often deeply-rooted method by which public officials take decisions in soft-states of Third World countries. Shleifer and Vishny [3] define government corruption as "the sale by government officials of government property for personal gain."For example, a military official selling military equipment procured by the government, for his personal gains. This is also manifested in trade, where custom officials working for the government often take bribes from companies at the ports and harbors. Treisman [4] also follows up and defined corruption as "the misuse of public office for private gain."

Jain [5] agrees on the definition of corruption as being acts in which the power of public office is being used for personal gains in a way that goes contrary to the rules of the game. He goes further to point out three elements that are required for corruption to thrive in a country: discretionary power, economic rents, and weak judicial system. Aidt [6] views corruption as a persistent feature of human societies over time and seems to be occurring in many societies due to three factors: discretionary power of government agents, economic rents, and weak political and administrative institutions. Svensson [7] also defined corruption as the misuse of public office for private benefits and can be a response to either beneficial or harmful laws. By this definition, the sale of government property by public officials, receiving of kickbacks in public procurement, and bribery and embezzlement of state funds, will all qualify as corruption. He went further to indicate that corruption is an outcome from a reflection of a country's legal, economic, cultural and political systems. Bardhan [8] further defined corruption as the use of public office for private gains. Akçay [9] also defined corruption as the misuse of public office for private benefit. This abuse emerges when a public official has monopoly power over a good or service and uses that power at his/her own discretion to accrue rent for him/ 
herself. He asserts that corruption is as a result of deep institutional weakness and can lead to inefficient economic, social, and political outcomes in a country.

Also, Rose-Ackerman and Palifka [10] defined corruption as the abuse of "entrusted power". Entrusted power in their definition encompasses the tasks an individual is expected to perform such as reviewing permit applications, passing laws, or hearing legal cases. This power is usually entrusted to government agents and broken when rules are subverted. The consequences being that the corrupt official acts inconsistently with his or her mandate, and has also sold a benefit that was not supposed to be provided on the basis of willingness to pay. Mungiu-Pippidi and Dadasov [11], defines corruption from micro and macro-theoretical frameworks. The micro -theoretical framework conceptualizes corruption from the principal-agent perspective. This explains corruption as the result of corrupt activities by agents for their personal gain, thereby betraying the interests of their principal who will typically be a top-level policy-maker. Corruption under the principal-agent framework assumes the existence of asymmetry information which prevents the principal from effectively monitoring and controlling the agent's behaviour. Therefore, the agents' involvement in corrupt activities is based on their own weighing of the expected costs and benefits of their actions. The macro-theoretical framework conceptualizes corruption at the country level by considering the structural and cultural settings of a country. This type of macro-theoretical framework is like that of Acemoglu and Robinson's [12] "inclusive and extractive institutions". While inclusive economic institutions promote economic growth and less corruption in a country, extractive institutions extract resources from the people by the few leaders and bred corruption ([12], pp.429-430).

From the definitions above, it appears that it is hard to define corruption precisely as it involves many aspects, many of which includes bribery, graft, nepotism, fraud, lobbying, embezzlement, kickbacks, and money laundering. All these acts deviate from a common acceptable form of good in society. Thus, corruption can be defined as any acts of deviation from good. Corruption is one of the worst crimes to be perpetuated on humanity, as people in corrupt nations suffer the faith of high illiteracy and school dropout rates, high rates of unemployment and crimes, and higher rates of poverty. The 2017 TI Corruption perception index[13] indicates that more than two-thirds of the 180 countries in the study, scored below 50, with an average score of 43 . The worst performing countries were in the Sub-Saharan Africa regions, with an average score of 32. In a 2015 Corruption in Africa survey conducted by TI [14], almost 75 million people in the Sub-Saharan Africa region were reported to have paid a bribe to government officials in the past year for various reasons. Also, out of 28 governments, 18 governments were completely failing to address corruption in the region and poor public service users were twice as likely as rich people to have paid a bribe to get a service or product from a government official. The presence of corruption in a country reduces the ability of the government to implement its basic public financé functions as it distorts resource allocations ([15], p.113). Corruption also erodes citizens' trust in the government, undermines social contracts, and has the potential to impede economic growth and development. However, many of the literature on corruption within Africa focuses on the principal-agent models and what governments can do to control corruption. The citizens-participation approach in the fight against corruption has been neglected. This paper fills the gap by discussing three approaches in combating corruption in the African continent with the inclusion of the citizens-participation approach. The paper is structured into four sections: introduction, common acts that qualify as corruption, the way forward, and conclusions.

\section{COMmon ACTS That Qualify AS CORRUPTION}

Corruption is most prevalent in developing countries and hurts the poor more, as developmental funds are being diverted by government agents for their private gains [16]. Corrupt officials in many instances do not steal physical cash from government institutions, as that would easily be detected. To avoid detection, they go through various ways to extract rents [17]. These methods of misconduct constitute acts of deviation from good. The term good used in this paper refers to anything that conforms to the moral order of society and will aide in the advancement or well-being of the entire society. For instance, the award of government contracts to solely families and friends by government officials, inflation of prices of goods and services during government procurement process, money laundering, and concealment of illegal wealth sources, all constitutes deviation from the moral order of society. These acts promotes rent-seeking behaviours through extraction of resources from the country by the few elites entrusted with power, to the detriment of the entire country's growth and development. Therefore, any acts of deviation from good can be termed corruption, as it seeks to 
deprive the entire society of its advancement and solely promote private gains for those government agents who are engaged in such acts. The common acts perpetuated by government agentsin Africa are summarized in Table 1.The term government agents used in this paper refers to both elected and non-elected government employees in a country, who are on government payroll and carry out day to day functions on behalf of the government and the citizenry.

Table1. Common acts that qualify as corruption

\begin{tabular}{|c|c|c|c|c|}
\hline Act & Definition & Example & \begin{tabular}{|c|} 
Good \\
\end{tabular} & Deviation From Good \\
\hline Bribery & $\begin{array}{l}\text { To induce } \\
\text { someone with } \\
\text { money or } \\
\text { gifts to act in } \\
\text { one's favor }\end{array}$ & $\begin{array}{l}\text { A customs officer taking money from } \\
\text { a company in exchange for their goods } \\
\text { entering the country without the } \\
\text { company paying the required taxes on } \\
\text { those goods. }\end{array}$ & $\begin{array}{l}\text { The custom officer's } \\
\text { duty is to monitor and } \\
\text { collect the required } \\
\text { amount of taxes from } \\
\text { each company before } \\
\text { allowing their goods } \\
\text { into the country. }\end{array}$ & $\begin{array}{l}\text { The customs officer takes } \\
\text { the bribe from the } \\
\text { company and enriches } \\
\text { his/her personal pocket. } \\
\text { The entire country loses on } \\
\text { the tax revenue from the } \\
\text { company, due to the } \\
\text { officer's act. }\end{array}$ \\
\hline Graft & $\begin{array}{l}\text { Use of one's } \\
\text { authority for } \\
\text { personal } \\
\text { gains }\end{array}$ & $\begin{array}{l}\text { A politician in charge of government } \\
\text { procurements having knowledge that } \\
\text { government needs to purchase cars for } \\
\text { officials. He then collaborates with a } \\
\text { car dealer to sell the cars above regular } \\
\text { market prices to the government, after } \\
\text { which the politician gets paid the price- } \\
\text { difference by the car dealer. }\end{array}$ & $\begin{array}{l}\text { The politician is to } \\
\text { purchase items at } \\
\text { regular market prices } \\
\text { on behalf of the } \\
\text { country if needed by } \\
\text { government. }\end{array}$ & $\begin{array}{l}\text { The politician reaps off the } \\
\text { state on this transaction, } \\
\text { for his personal } \\
\text { enrichment. The entire } \\
\text { country loses revenue. }\end{array}$ \\
\hline Nepotism & $\begin{array}{l}\text { Deliberately } \\
\text { favoring } \\
\text { relatives and } \\
\text { friends in job } \\
\text { applications }\end{array}$ & $\begin{array}{l}\text { A director of a government institution } \\
\text { in charge of Police officers' } \\
\text { recruitment. He influences the } \\
\text { recruitment process by favoring only } \\
\text { his tribesmen and neglecting other } \\
\text { tribes in the country. }\end{array}$ & $\begin{array}{l}\text { The director is to } \\
\text { make the recruitment } \\
\text { process fair for every } \\
\text { qualified citizen in the } \\
\text { country and not be } \\
\text { selective. }\end{array}$ & $\begin{array}{l}\text { The director plays } \\
\text { favoritism and only } \\
\text { focuses on his tribesmen. } \\
\text { Other citizens are deprived } \\
\text { of an opportunity for } \\
\text { employment. }\end{array}$ \\
\hline Fraud & $\begin{array}{l}\text { Deliberately } \\
\text { using } \\
\text { deception to } \\
\text { cause } \\
\text { financial lost } \\
\text { to the State. }\end{array}$ & $\begin{array}{l}\text { A CEO of a government institution } \\
\text { inserting names of non-existing } \\
\text { employees on government payroll } \\
\text { (ghost names) to inflate the payroll. }\end{array}$ & $\begin{array}{l}\text { The CEO is to ensure } \\
\text { only existing workers } \\
\text { within his institution } \\
\text { are on government } \\
\text { payroll. }\end{array}$ & $\begin{array}{l}\text { The CEO does the } \\
\text { opposite and inflates the } \\
\text { government payroll with } \\
\text { ghost names and receives } \\
\text { the salaries. He enriches } \\
\text { himself through this act } \\
\text { and causes financial lost to } \\
\text { the State. }\end{array}$ \\
\hline Lobbying & $\begin{array}{l}\text { Influencing } \\
\text { government } \\
\text { agent on an } \\
\text { issue. }\end{array}$ & $\begin{array}{l}\text { Mining companies wanting to } \\
\text { maximize its profits decides to donate } \\
\text { money to the campaign of a group of } \\
\text { politicians, to influence them to vote } \\
\text { "yes" in the house of Parliament on a } \\
\text { tax cut that will benefit the mining } \\
\text { companies. }\end{array}$ & $\begin{array}{l}\text { The Politician is to } \\
\text { vote on what is best } \\
\text { for the citizens in the } \\
\text { country and not what } \\
\text { is best for the mining } \\
\text { company. }\end{array}$ & $\begin{array}{l}\text { The Politician votes "Yes" } \\
\text { instead of "No." The } \\
\text { politician and the mining } \\
\text { companies gains. The } \\
\text { country loses tax revenue } \\
\text { from the mining } \\
\text { companies, which further } \\
\text { slows down development. } \\
\end{array}$ \\
\hline $\begin{array}{l}\text { Embezzl } \\
\text { e } \\
\text { ment }\end{array}$ & $\begin{array}{l}\text { Illegal use of } \\
\text { money under } \\
\text { one's control. }\end{array}$ & $\begin{array}{l}\text { An Accountant of a government } \\
\text { institution using the institution's funds } \\
\text { for his personal gain. }\end{array}$ & $\begin{array}{l}\text { The Accountantduty } \\
\text { is to use the funds } \\
\text { purposely for what it } \\
\text { is meant for in the } \\
\text { government } \\
\text { institution. }\end{array}$ & $\begin{array}{l}\text { The Accountant does the } \\
\text { opposite and uses the } \\
\text { money for his personal } \\
\text { gains, causing financial } \\
\text { lost to the State. }\end{array}$ \\
\hline Kickback & $\begin{array}{l}\text { Payment to a } \\
\text { government } \\
\text { agent by a } \\
\text { bidder for } \\
\text { favoring him } \\
\text { to win a } \\
\text { contract. }\end{array}$ & $\begin{array}{l}\text { A Politician in-charge of roads } \\
\text { Ministry awards a road contract to a } \\
\text { construction company at an inflated } \\
\text { cost and gets paid } 10 \% \text { of the total } \\
\text { contract sum by the construction } \\
\text { company, for assisting them to win the } \\
\text { contract. }\end{array}$ & $\begin{array}{l}\text { The Politician is to } \\
\text { conduct a fair bidding } \\
\text { process and select } \\
\text { value-for-money. }\end{array}$ & $\begin{array}{l}\text { The Politician does the } \\
\text { opposite and inflates the } \\
\text { contract sum and gets } 10 \% \\
\text { as kickback from the } \\
\text { construction company. } \\
\text { The politician gains } \\
\text { financially and causes } \\
\text { financial lost to the State. }\end{array}$ \\
\hline Money & Concealing & A Politician collecting bribe from an & Politician & The Politician deviates \\
\hline
\end{tabular}




\begin{tabular}{|c|c|c|c|c|}
\hline $\begin{array}{l}\text { Launde } \\
\text { ring }\end{array}$ & $\begin{array}{l}\text { the source of } \\
\text { illegal } \\
\text { money. }\end{array}$ & $\begin{array}{l}\text { Oil company in exchange for the } \\
\text { company paying less percentage of } \\
\text { royalties to the nation. In other to hide } \\
\text { this illegal money, he transfers it to a } \\
\text { celebrity friend in the art industry. The } \\
\text { State thinks the celebrity's wealth is } \\
\text { solely through his/her career and thus } \\
\text { no investigations are made into his/her } \\
\text { source of wealth by State institutions. } \\
\text { The bribe is successfully concealed by } \\
\text { the Politician. }\end{array}$ & $\begin{array}{l}\text { supposed to sign } \\
\text { contracts to benefit } \\
\text { the country and not } \\
\text { the Oil company. }\end{array}$ & $\begin{array}{l}\text { from good and benefits } \\
\text { personally. The country } \\
\text { loses out on revenue as the } \\
\text { percentage due to the } \\
\text { nation in royalties is } \\
\text { reduced. }\end{array}$ \\
\hline
\end{tabular}

\section{THE WAY FORWARD}

\subsection{Increasing Punishments for Acts of Corruption.}

In some instances, government agents who are caught in the act of corruption are only made to refund the amount involved without any repercussions to them. In situations where they are penalized, the punishment is far less than the rewards for deviation from good. This makes acts of corruption more lucrative in African countries. One way to hinder progression of this is to increase the punishment on acts of corruption. For instance, suppose a government agent currently earns $Y$ income annually and the agent derives utility according to the utility function $U=Y$. The agent also faces a $p$ probability of a loss in choosing either to deviate or not deviate from good. If he deviates from good, he earns $B$ and if he is caught for deviation, he faces a jail term of 12 months or an equivalent penalty of $M$ amount. From the above scenario, two cases can be derived:

Case 1: If the agent does not deviate from good (No corruption)

Loss: $Y(P)$

Gain: $Y(1-P)$

Expected utility $\left(E U^{0}\right)=P U(Y)+(1-P) U(Y)$

Case 2: If the agent deviates from good (Corruption)

Loss: $\quad Y+B-B-M(P)$

Gain: $\quad Y+B(1-P)$

Expected Utility $\left(E U^{1}\right)=P U(Y-M)+(1-P) U(Y+B)$

In case 1 , the agent enjoys the same utility from his wealth and does not lose or gain in choosing not to deviate from good. Case 2 shows that the agent enjoys a new utility if he chooses to deviate from good. However, if he deviates and gets caught, he faces a penalty $M$ as well as the recovery of the deviation amount $B$. On the other hand, if he deviates and does not get caught, he gains the deviation amount $B$ plus his initial income $Y$. Following this argument and with the assumption that the agent has an equal probability of a loss or gain, then it is best to assume that the agent will choose to deviate from good if $E U^{1}>E U^{0}$. Therefore, to stop an agent from this divergence, $M$ must be increased. If $M$ increases, it reduces the agent's new expected utility $\left(E U^{1}\right)$ as shown below:

$\frac{\partial E U^{1}}{\partial M}=-P U(Y-M)<0$

Thus as $M$ increases, the new expected utitlity $\left(E U^{1}\right)$ decreases, making it unappealing for the agent to deviate from good. Case 1 and 2 could further be explained with the following three (3) examples below:

\section{Example 1: $M<B$}

Suppose a government agent currently earns $\$ 60,000$ income annually. The agent derives utility according to the utility function $U=Y$ and faces a 0.5 probability of a loss in choosing either to deviate or not deviate from good. If he deviates from good, he earns $\$ 5000$ and if he is caught, he faces a jail term of 12 months or an equivalent penalty of $\$ 4000$.

Case 1: If the agent does not deviate from good (No corruption)

Loss: $\$ 60000(0.5)$ 
Gain: $\$ 60000(1-0.5)$

Expected utility $\left(E U^{0}\right)=0.5(\$ 60000)+(1-0.5)(\$ 60000)=\$ 60000$

Thus, if the agent does not deviate from good, his loss and gain remain the same and the expected utility is $\$ 60,000$.

Case 2: If the agent deviates from good (Corruption)

Loss: $\quad \$ 60000+\$ 5000-\$ 5000-\$ 4000(0.5)$

Gain: $\quad \$ 60000+\$ 5000 \quad(1-0.5)$

Expected Utility $\left(E U^{1}\right)=0.5(\$ 56000)+(1-0.5)(\$ 65000)=\$ 60,500$

Therefore $E U^{1}>E U^{0}$, implying the agent will choose to deviate from good since it offers higher expected utility $\left(E U^{1}\right)$ than not deviating from good $\left(E U^{0}\right)$.

Example 2: $M=B$

Suppose a government agent currently earns $\$ 60,000$ income annually. The agent derives utility according to the utility function $U=Y$ and faces a 0.5 probability of a loss in choosing either to deviate or not deviate from good. If he deviates from good, he earns $\$ 5000$ and if caught, he faces a jail term of 18 months or an equivalent penalty of $\$ 5000$.

Case 1: If the agent does not deviate from good (No corruption)

Loss: $\$ 60000(0.5)$

Gain: $\$ 60000(1-0.5)$

Expected utility $\left(E U^{0}\right)=0.5(\$ 60000)+(1-0.5)(\$ 60000)=\$ 60000$

Case 2: If the agent deviates from good (Corruption)

Loss: $\quad \$ 60000+\$ 5000-\$ 5000-\$ 5000(0.5)$

Gain: $\quad \$ 60000+\$ 5000 \quad(1-0.5)$

Expected Utility $\left(E U^{1}\right)=0.5(\$ 55000)+(1-0.5)(\$ 65000)=\$ 60,000$

Therefore $E U^{1}=E U^{0}$, implying there is no incentive for the agent to deviate from good since deviating yields same utility as not deviating.

Example 3: $M>B$

Suppose a government agent currently earns $\$ 60,000$ income annually. The agent derives utility according to the utility function $U=Y$ and faces a 0.5 probability of a loss in choosing either to deviate or not deviate from good. If he deviates from good, he earns $\$ 5000$ and if caught, he faces a jail term of 24 months or an equivalent penalty of $\$ 6000$.

Case 1: If the agent does not deviate from good (No corruption)

Loss: $\$ 60000(0.5)$

Gain: $\$ 60000(1-0.5)$

Expected utility $\left(E U^{0}\right)=0.5(\$ 60000)+(1-0.5)(\$ 60000)=\$ 60000$

Case 2: If the agent deviates from good (Corruption)

Loss: $\quad \$ 60000+\$ 5000-\$ 5000-\$ 6000(0.5)$

Gain: $\quad \$ 60000+\$ 5000 \quad(1-0.5)$

Expected Utility $\left(E U^{1}\right)=0.5(\$ 54000)+(1-0.5)(\$ 65000)=\$ 59500$

Therefore $E U^{1}<E U^{0}$, implying the agent would not deviate from good since choosing to deviate offers a lower expected utility.

From the three examples, it is practically apparent that increasing the penalty $(M)$ on deviation from good, reduces the expected utility that agent gets. Therefore, the agent would not want to deviate from good knowing the punishment that awaits him, if caught, are far greater than the gains. Thus, African governments should increase the punishment meted out to government agents found to be corrupt under the laws, to be able to win the fight against corruption. 


\subsection{Increasing the Probability of Detection}

Increasing punishments for acts of corruption without increasing the probability of detection ([18], p.47) of government agents involved in acts of corruption, would amount to no results and the fight against corruption would be lost. The fact that the two parties participating in a bribe often benefit mutually, bribery and other acts of deviation from good can be extremely difficult to detect [19]. However, an agent would avoid engagement in acts of corruption if he knows there are higher punishments that awaits him, combined with the knowledge that there are higher chances of him being caught for engaging in such acts. There are two ways to increase the chances of prosecution on government agents: rewards and protection for whistleblowers, and installations of security gadgets at all government institutions. Acts of corruption are punishable offenses under the laws of almost every African country[20]. However, government officials still get away with these acts and African countries continue to lose an increasing amount of funds every day mainly because people that witness these acts committed by others never take a bold step to report them to the authorities for the participatory culprits to face the law. The witnesses often fear that they would be left to their fate without any protection from the government if they report such occurrences to the authorities. Individuals are most likely to report acts of corruption of government agents to the authorities if there are rewards and protections associated with whistle blowing. Protection of whistleblowers should come in the form of assuring their anonymity from the public and a compensation for taking bold steps to report wrongdoings of government agents. This would lead to a more citizen-based participation in assisting governments in the fight against corruption. For example, the United States has a statute that protects those who report irregularities in government institutions. This is known as "6 U.S. Code $§ 625$. Whistle blower protections" [21].

Aside this, African governments should also increase the probability of detecting agents involved in wrongful acts, by investing in more advanced security devices. Monitoring and collecting information about government agents can be a source of detecting and prosecuting dishonest agents ([22], p. 508). In countries such as Europe, Asia or the Americas, there are surveillance cameras in government institutions and as well as private organizations. However, this is not the case in African countries. You can walk through a government port and harbor, or revenue collecting agency, without finding any surveillance cameras. In an instance that you find surveillance cameras, chances are that, they may not be working properly. In short, African governments lack the desire to invest in advanced surveillance technologies for their institutions. Installing advanced surveillance technologies in government institutions would reduce the level of acts of corruption occurring throughout the continent. Agents would be naturally more cautious in their actions knowing that they are being watched and recorded visually and audibly on cameras, therefore, the probability of them engaging in corrupt acts would reduce greatly.

\subsection{Commercializing the Fight against Corruption}

Corruption is widespread in developing countries because conditions are fitting for it and also the motivation held by citizens to earn income is extremely high [19].Therefore, acts of corruption have become one of the quickest ways to get rich in Africa because it is a lucrative business for government agents to engage in, making the continent lose over 50 billion US dollars annually due to corruption [23]. Those involved in acts of corruption are mostly partisan related to the ruling government in many African countries, making it hard for the government to prosecute them in the law court. Thus, the very individuals who are supposed to protect the nations' funds and prosecute these corrupt government agents, may be the same individuals shielding them. To avoid cases of this nature, African governments should commercialize the fight against corruption. Citizens of African origin and donor agencies operating in Africa should be given the chance to take government agents to the law court either in the country or abroad, and in the event of a case being won and punishment meted out, a percentage of the amount reclaimed should be paid to the citizen or donor agency for winning the case for the nation. For example, a government agent is alleged to have taken a bribe of $\$ 10$ million from a foreign company. A citizen of the country or a donor agency operating in the country gets the information, takes the case to court (locally or internationally) and incurs a lawyer's fee of $\$ 1$ million. The citizen/donor agency wins the case and the court orders a repayment of the bribe money and a penalty of $\$ 15$ million by the government agent to the country. The country gains $\$ 25$ million in revenue due to the citizen's/donor agency's effort and pays $10 \%$ of the total revenue gained to the citizen/donor agency as a reward. The citizen/donor agency earns $\$ 1.5$ million profit and 
the country also gains $\$ 22.5$ million revenue in the end. Therefore, commercializing the fight against corruption and involving citizens' participation, would be a win situation for African governments in the fight to end corruption within the continent. However, this may call for an amendment of the constitutions of many African countries to make provisions for this approach of fighting corruption. By so doing, fighting acts of corruption will become a commercial affair in which citizens would be more willing to participate.

\section{CONCLusions}

While the President of Ghana, Nana Akufo-Addo, is calling on Africa to move beyond aid and not be 'beggars of the world' [24], a vast amount of revenue have been lost to corruption within the continent. Funds that could have been used for developmental purposes in African countries to propel economic growth and sustainable development, are lavishly being squandered by government agents. For instance, Mobutu Sese Seko, the former President of Democratic Republic of Congo (formerly called Zaire), squandered a fortune of 5 billion US dollars from the country's treasure, which was equal to the country's entire external debts before he was ousted in 1997([7]; [25]). In 2001, an International Monetary Fund (IMF) report indicated that nearly 1 billion US dollars of oil revenues disappeared from Angolan national treasury, which was equivalent to about three times of the amount received by the country in humanitarian aid[7]. A study found that health care workers in Uganda were stealing 78 percent of drug supplies and selling it for personal gains. This dramatically reduced health care service delivery to the poor citizens [25]. Also, Karimi and Diop [26] reported of the France corruption trial of Teodoro Nguema Obiang Mangue's, Vice President of Equatorial Guinea and who also happens to be the son of Equatorial Guinea's President, for splurging on a Parisian mansion, a private jet and a fleet of luxury cars using tens of millions of dollars he allegedly amassed from his country. Whilst Mr. Teodoro squandered millions of dollars of his countries revenue on private jet, and fleet of luxury cars, Equatorial Guinea was on foreign aid and received Net Official Development Assistant (ODA) to the tune of 6.9 million dollars in 2017 [27].Furthermore, while former President of South Africa, Jacob Zumah, faces a 5 billion US dollar corruption charge [28], the people of South Africa are on the streets rioting over poor services and increasing poverty in the country [29]. These few examples mentioned, paired with undocumented cases of corruption, points to the fact that corruption in Africa is still prevalent and the fight is not over. Increasing punishments for offenders, and the methods of detecting acts of corruption, as well as commercializing the fight against corruption, would provide a great foundation and a way forward for tackling corruption effectively by African governments.

\section{REFERENCES}

[1] TI (Transparency International), "HOW DO YOU DEFINE CORRUPTION?", 2017, https://www .transparency.org/ what-is-corruption\#define (Accessed August 30, 2018).

[2] Macrae, J., "Underdevelopment and the Economics of Corruption: A Game Theory Approach", World Development. vol. 10 no.8, 1982, pp.677-687.

[3] Shleifer, A. and Vishny, R. W., "Corruption", The Quarterly Journal of Economics, vol. 108 no. 3, 1993, pp.599-617.

[4] Treisman, D., "The Causes of Corruption: a Cross-National Study", Journal of Public Economics, vol. 76 no. 3, 2000, pp.399-457.

[5] Jain, K. A., "Corruption: A Review”, Journal of Economic Surveys,vol. 15 no. 1, 2001, pp.71-121.

[6] Aidt, T. S., "Economic Analysis of Corruption: A Survey", The Economic Journal, 113, 2003, pp.632-652.

[7] Svensson, J., "Eight Questions about Corruption", Journal of Economic Perspectives, vol. 19 no. 3, 2005, pp.19-42.

[8] Bardhan, P., "The Economist's Approach to the Problem of Corruption”, World Development,vol. 34 no. 2, 2006, pp.341-348.

[9] Akçay, S., "Corruption and Human Development", Cato Journal,vol. 26 no. 1, 2006, pp.29-48.

[10] Rose-Ackerman, S., and Palifka, B. J., "Corruption and Government: Causes, Consequences, and Reform", 2nd ed., Cambridge University Press, New York (2016)

[11] Mungiu-Pippidi, A., and Dadasov, R., "Measuring Control of Corruption by a New Index of Public Integrity", SSRN Electronic Journal, 2016, https://doi.org/10.2139/ssrn.2828086 (Accessed January 5, 2019).

[12] Acemoglu, D., and Robinson, J. A., "Why Nations Fail: the Origins of Power, Prosperity, and Poverty", Profile Books, London (2012). 
[13] TI (Transparency International), “Corruption Perception Index 2017”, 2018,https://www.transparency. org/news/feature/corruption_perceptions_index_2017 (Accessed August 30, 2018).

[14] TI (Transparency International), “Corruption in Africa: 75 Million people pay bribes”, 2015, https://www. transparency.org/news/feature/corruption_in_africa_75_million_people_pay_bribes (Accessed January 10, 2018).

[15] Tanzi, V., "Corruption and the Budget: Problems and Solutions", in Jain, A. K. (Eds), "Economics of Corruption",Kluwer Academic, Boston, 1998, ch. 6, pp.111-128.

[16] Khezri, M., and Mangor, S., “Approaches to Corruption in the Developing Countries", International Journal of Political Science, vol. 4 no.7, 2014, pp.38-53.

[17] Olken, B.A., and Pande, R., "Corruption in Developing Countries", National Bureau of Economic Research Working Paper Series, 17398, 2011, http://www.nber.org/papers/w17398.pdf (Accessed September 11, 2018).

[18] Rose-Ackerman, S., "The Political Economy of Corruption”, in Elliott, K. A. (Eds), "Corruption and the Global Economy”, Institute for International Economics. Washington DC, 1997, ch. 2,pp.31-60.

[19] Gray, C. W., and Kaufman, D., "Corruption and Development”, PREM Notes; No. 4. World Bank, Washington, DC. (C) World Bank. License: CC BY 3.0 IGO, 1998.

[20] Kofele-Kale, N., "Change or the Illusion of Change: The War against Official Corruption in Africa", George Washington International Law Review,vol. 38 no. 4, 2006, pp.697-748.

[21] Cornell Law School, "legal Information Institute: 6 U.S. Code §625.Whistleblower protections", https://www.law.cornell.edu/uscode/text/6/625 (Accessed January 3, 2019).

[22] Ades, A., and Di Tella, R., "The New Economics of Corruption: A Survey and Some New Results", Political Studies, vol. 45 no. 3, 1997, pp.496-515.

[23] TI (Transparency International), "HOW TO WIN THE FIGHT AGAINST CORRUPTION IN AFRICA", 2018, https://www.transparency.org/news/feature/how_to_win_the_fight_against_corruption_in_africa (Accessed January 3, 2019).

[24] Suliman, A., "Africans must move beyond aid and not be 'beggars of the world': Ghana's president", Reuters, November 21, 2017,https://www.reuters.com/article/us-britain-ghana-aid/africans-must-move-beyond-aid-andnot-be-beggars-of-the-world-ghanas-president-idUSKBN1DL2JC (Accessed August 22, 2018).

[25] Thomas, M. A., "Getting Debt Relief Right”, Foreign Affairs, vol. 80 no. 5, 2001, pp.36-45.

[26] Karimi, F., and Diop, M., "Bugattis, Ferraris and yachts, oh my! African vice president on trial in Paris", CNN, June 23, 2017, https://www.cnn.com/2017/06/23/africa/france-trial-teodoro-nguema-obiangmangue/index.html (Accessed October 30, 2018).

[27] OECD (Organization for Economic Cooperation and Development), "Aid at a glance charts: Interactive summary charts by aid (ODA) recipients”, 2018, http:/www.oecd.org/countries/equatorialguinea/aid-at-aglance.htm (Accessed January 3, 2019).

[28] Onishi, N., "Jacob Zuma to Be Prosecuted on Corruption Charges", TheNew York Times, March 16, 2018, https://www.nytimes.com/2018/03/16/world/africa/jacob-zuma-south-africa-corruption.html (Acce ssed June 10, 2018).

[29] Stoddard, Ed.,"South African riots over poor services, poverty hit record in 2018”, Reuters, October 17, 2018, https://af.reuters.com/article/topNews/idAFKCN1MR2GN-OZATP(Accessed October 30, 2018).

\section{AUTHORS' BIOGRAPHY}

Sa-ad Iddrisu is a PhD Candidate at the Department of Economics, Wayne State University, United States. He is a current recipient of the Wayne State University Doctoral scholarship from 2015-2019. $\mathrm{He}$ also a former recipient of the Dawood Farahi Public Service Endowed scholarship at Kean University for the academic year 2011-2012. His main research interests lie in the fields of Macroeconomic Policy, Corruption and Health Economics. He is particularly interested in the growth and development of developing countries. He received a B.A degree from University for Development Studies, Ghana, and MPA degree from Kean University, United States.

Citation: Sa-ad Iddrisu. "Corruption in Africa: The Way Forward ". International Journal of Political Science (IJPS), vol5, no.1, 2019, pp. 22-29. doi:http://dx.doi.org/ 10.20431/2454-9452.0501004.

Copyright: (C) 2019 Authors. This is an open-access article distributed under the terms of the Creative Commons Attribution License, which permits unrestricted use, distribution, and reproduction in any medium, provided the original author and source are credited. 